\title{
POTENTIAL OF REUSAM ISLAND TO BECOME SHARIA ECOTOURISM AREA
}

\author{
Izwar IZWAR \\ Universitas Sumatera Utara, Environtmental Study, Faculty of Postgraduate, \\ Street of Dr Mansyur 12, Padang Bulan, Medan, North Sumatera, Indonesia, 20155, e-mail: izwar@usu.ac.id

\section{Badaruddin BADARUDDIN"} \\ Universitas Sumatera Utara, Sociology Program, Faculty of Political and Social Science, \\ Street of Dr Mansyur 12, Padang Bulan, Medan, North Sumatera, Indonesia, 20155, e-mail: badaruddin@usu.ac.id

\section{Miswar Budi MULYA} \\ Universitas Sumatera Utara, Environtmental Study Program, Faculty of Postgraduate, \\ Street of Dr Mansyur 12, Padang Bulan, Medan, North Sumatera, Indonesia, 20155, e-mail: miswar@usu.ac.id \\ Robert SIBARANI \\ Universitas Sumatera Utara, Culture Study Program, Faculty of Postgraduate, \\ Street of Dr Mansyur 12, Padang Bulan, Medan, North Sumatera, Indonesia, 20155, e-mail: robert@usu.ac.id

\begin{abstract}
Citation: Izwar, I., Badaruddin, B., Mulya, M.B., \& Sibarani, R. (2020). POTENTIAL OF REUSAM ISLAND TO BECOME SHARIA ECOTOURISM AREA. GeoJournal of Tourism and Geosites, 30(2spl), 827-834. https://doi.org/10.30892/gtg.302spl07-511
\end{abstract}

\begin{abstract}
This study aims to see the potential and carrying capacity of Reusam Island in accordance with the needs of the ideal Halal ecotourism area in Aceh Jaya, Indonesia. This research is a survey research, the data used in this study consists of primary data and secondary data. Data on the potential of ecotourism, natural resource capacity and the application of Islamic Sharia were obtained through distributing questionnaires to 660 samples. Based on the analysis it was found that the potential carrying capacity of Reusam Island was generally in accordance with the needs of the Halal ecotourism area in Aceh Jaya, including weather changes, efforts to anticipate the high waves and the graceful, the manager of the Reusam Island tourist area took a stand by not carrying out crossings to the island. Support to go to Reusam Island, another problem, the lack of management officers both in terms of quantity and quality. Public response about the capacity of natural resources on the island of Reusam to be used as an ecotourism area, almost all items received positive responses from visitors, except about the coral reefs on the island of Reusam which are used for diving and snorkeling destinations. Public response to the ecotourism potential of Reusam Island received a positive response, except in terms of Government support for the management of the ecotourism area on Reusam Island, most of the endorsers still doubted the commitment of the local government. As for Sharia tourism, all respondents agreed on Reusam Island to be a Sharia ecotourism area.
\end{abstract}

Key words: Reusam Island, Tourist Arrivals, Aceh Jaya, Ecotourism, Sharia

\section{INTRODUCTION}

Indonesia in general has the potential to become a world tourist destination in various forms, both cultural, natural and religious tourism. For cultural tourism, we can see the diversity of tribes and cultures in Indonesia, one of which is in Jokjakarta, while nature tourism is strongly supported by the natural beauty in Indonesia, such as Bali and NTB. In addition to cultural and natural tourism, the development of religious tourism has also increased, we can see this, one of which is the visit of the people to visit the Ulama Cemetery, as well as historical heritage sites related to other religions. According to Butar and Soemarno (2013), Indonesia is a country rich in natural and cultural resources. The country's territory, which consists of more than 17,000 islands stretching along $6400 \mathrm{~km}$ from West to East, and around 3,000 km from North and South, naturally has high diversity. Indonesia has diverse resources such as the availability of the Greater Sunda Islands (Sumatra, Kalimantan, Java and Bali). With capital of ethnic and cultural diversity, and supported by natural resources, Indonesia has become one of the world's tourist destinations, so that in developing the tourism area in the future, it will not be too difficult, because the main capital in the form of cultural and natural wealth has been owned by the Indonesian people (Vujko et al., 2018; Perbawasari et al., 2019b). In addition, there is currently a shift in the orientation of the tour, from mass tourism to special interst tourism (Tondang, 2007; Sembiring et al., 2019). The shift occurred from cultural tourism towards more natural tourism (Lubis, 2013). A similar sentiment was also conveyed by Kilipiris and Zardaya (2012), where there is a shift from tourists who prefer to protect the environment and culture which are oriented towards tourism. This difference is one of the factors that causes the number of foreign tourists visiting Aceh to continue to increase from year to year. One area that has the potential to develop ecotourism areas is Aceh Jaya District. Aceh Jaya is a district that was formed in 2002 precisely on April 10, the result of the division of Aceh Barat District. The geographical situation of Aceh Jaya Regency is not much different from the other South West Aceh regions, most of the area is a coastal area with an area of $3.813 \mathrm{~km}^{2}$ (BPS, 2013), with a coastline length of $+/-160 \mathrm{~km}^{2}(\mathrm{BPS}, 2013)$.

When viewed from the vast coastal area of Aceh Jaya, which is mostly coastal areas, it has attractive tourist destinations to visit, among others, Ceumara Teunom Beach, Pasi Panga Beach, Reusam Island. Calang Beach, Pasie Saka Beach, Gunung Geurute Cliffs, Lhok Geulumpang Beach. The places mentioned are some coastal areas in Aceh Jaya which have the potential to become ecotourism areas. One of the tourist attractions above, is the object of this research, namely Reusam Island. Reusam Island is located in Aceh Jaya Regency, precisely in the Bay of Rigaih, Setia Bakti District, is a tourist area that has natural potential with attractive coastal areas and ecological richness that is still beautiful. This is supported by the Government of Aceh Jaya Regency, by making Reusam Island a conservation area Coral reefs.

\section{LITERATURE REVIEW}

\section{Ecotourism}

Increasing population, is directly proportional to the interest of the community to travel, without realizing it has a direct impact on

\footnotetext{
"Corresponding author
} 
environmental degradation that is increasing due to human activities in the tourism sector, both intentionally or not. According to Baksir (2010) ecotourism is actually a combination of various interests that grow based on environmental, economic and social concerns. In other words, ecotourism is a model of tourism development that respects the rules of nature by implementing an integrated development and conservation program between efforts to conserve natural resources and the sustainable development of the community's economy (Fandeli and Mukhlison, 2000; Buchsbaum, 2004; Kolosinska et al., 2018; Pohan et al., 2018; Schlüter and Schumann, 2018). From the explanation of the opinions of the experts above, ecotourism is a nature tourism activity and having a destination in addition to enjoying the beauty of nature is also responsible for environmental conservation in the areas visited by tourists (Eshun et al., 2019). The same time generate income for the region or the local community, where part of the income is used for environmental conservation.

\section{Potential of Coastal Areas and Islands as Ecotourism Areas}

Coastal area is a strategic area that determines the quality of land, this is because the coastal area has a free relationship with the open sea and receives fresh water input from the mainland. Meanwhile, according to Adrianto (2004), in the perspective of ecosystems in coastal areas, the area of small islands can be divided into several sub-regions, namely: (1) coastal offshore zones; beach area (beach zone); (3) coastal lowland zone; (4) inland zone. Judging from the complexity and beauty of the coastal area, it makes it an ecotourism area that is often visited, both as tourists and researchers. The most common pollution we encounter in tourist areas includes physical, biological and impacts on wildlife including animal disturbance and feeding (Muda and Wahyuni, 2019). Other impacts include littering, collections of artifacts, graffiti and damage to coral reefs (Farrell and Marion, 2001). Environmental damage will continue if the management of tourist areas without environmental basis (ecotourism), for example environmental degradation that occurred in Honduras found by Stonich (1998) in Zambrano et al., (2010) found that tourism in Honduras caused significant environmental degradation which affects the health of the local population. In addition, the sustainability of ecotourism can be questioned and disrupted if the destiny requires a long journey, as a result it will have a global impact because the farther away the ecotourism destination the more fossil energy needed by Marzouki et al., (2012). Efforts to anticipate degradation, is by requiring the island and coastal areas which are encapsulated by ecotourism areas should get the attention of all parties, especially in development and management.

Baksir (2010) explains the understanding of small island management is a process of planning, utilization, supervision, and control of small island resources whose area is $=2.000 \mathrm{~km}^{2}$, functionally interacting from the ecological, economic, socio-cultural aspects both individually and synergistically can improve the welfare of the community. The achievement of the Indonesian government's targets through the ministry of tourism have five main targets for the 2014-2019 period:

a. First, the contribution of tourism to Gross Domestic Product (GDP) increased from $9 \%$ in 2014 to $15 \%$ in 2019. As of November 2015, tourism's contribution to GDP was $9.5 \%$;

b. Secondly, foreign exchange increased from IDR 140 Trillion in 2014 to IDR 280 Trillion in 2019. Currently the contribution of tourism to the National GDP is estimated to reach $4 \%$ with foreign exchange of IDR 155 Trillion;

c. Third, the contribution to employment opportunities increased from 11 Million in 2014 to 13 Million in 2019;

d. Fourth, the tourism competitiveness index increased from 70 in 2014 to 30 in 2019;

e. Sixth, the number of domestic tourist trips increased from 250 Million in 2014 to 275 Million in 2019 (Kemenpar, 2015 in Widagdyo, 2015).

\section{Coastal Resources for Ecotourism}

Coastal zones are defined as geomorphological areas on both sides of the coast where biotic and abiotic components of the marine and terrestrial environment interact to form complex ecological and economic resource systems, where human populations, both residents and tourists, carry out their activities. social, recreational and commercial activities (UNEP(DEC)MED, 2005 about Integrated Coastal Zone Management in the Mediterranean. Meeting of the MAP Focal Points. Athens, Greece, 21-24 September 2005). The resources contained in the coastal area make it one of the centers of world civilization, so it is not impossible to see, when there was an earthquake and tsunami disaster in Aceh Province, thousands of people became victims, this proves the coastal area is the center of human life activities. According to Ozyurt and Ergin (2009) Coastal areas have historically been used for human settlements because of the abundance of natural resources needed for survival and development (Ozyurt and Ergin, 2009). Unspoiled coastal areas, including beaches, dunes, wetlands and forests, provide valuable ecosystem benefits, such as storm surges, recreational opportunities, carbon storage, habitat provision, temperature regulation, and water quality improvement (Spalding et al., 2014). This protected area can protect the community from the impacts of climate change (Arkema et al., 2013). The existence of the coastal area, the benefits are felt by the community in general, especially those domiciled in the region, for example the benefits of the coastal area in the UK, as described by Jones et al., (2011) identified that although coastal habitats only occupy $0.6 \%$ of the area mainland England, they account for around $£ 48$ Billion (adjusted to 2003 values) of ecosystem benefits. While in the United States, which in total, 14.7 Million hectares of land covering 15 protected states along the US east coast, account for more than $20 \%$ of the land area on the east coast (Niell et al., 2017). This area protects coastal communities from damage due to climate change, but the fact is that coastal areas themselves receive the effects of climate change such as rising sea levels. The level of global sea level rise averaged 0.13 Inches $(3.11 \mathrm{~mm}$ ) per year between 1993 and 2008, as identified by satellite data (Ablain et al., 2009).

\section{Mangrove Ecosystem}

Mangrove ecosystems are intertidal wetlands in sub-tropical or tropical coastal areas. This ecosystem has a key role in (i) biogeochemical cycles in tropical estuary ecosystems, (ii) sustainability of the coastal ecological system, (iii) support for aquaculture or (iv) stabilization of tropical coastlines (Kurniawan et al., 2014). Similar opinion was also conveyed by Gong et al., (2017), mangrove ecosystems have a large capacity to hold heavy metals, high copper concentrations have been recorded in mangrove deposits throughout the world now (Gong et al., 2017). Strong and sturdy mangrove roots make this ecosystem function to maintain the stability of the coast from the effects of erosion, waves and abrasion, protection of the land, Tsunami, typhoon, sea water intrusion, and the threat of various pollutants and pathogens, ecologically, mangrove ecosystem functions as a buffer for ecological balance between life on land and sea (Umilia and Asbar, 2016). Besides mangrove plants also become a source of energy for many marine biota species such as fish, shrimp, shellfish, crabs and various other types of biota, spawning land, rearing, animal feed and as a place to live (Umilia and Asbar, 2016). Economically, mangrove ecosystems function as suppliers of products that bring economic benefits to humans, such as providers of recreational facilities, education, aquaculture and animal husbandry and providers of products for fuel, paper, construction, household appliances, textiles, leather, food, drinks and medicines (Salm et al., 2000). According to Nanlohy et al., (2015), this is caused by the very low level of knowledge and concern. In the study of Nanlohy et al., (2015) the data shows that the percentage of the level of public knowledge about climate change is very low only in $26.67 \%$ of people in the Bay of Kotania who know about climate change, while the community of $73.33 \%$ never knew about climate change. 


\section{Lamun Ecosystem}

Lamun are plants that float in the sea, which form broad grasslands in shallow coastal waters on all continents except Antarctica (Short et al., 2007). Besides seagrass is also known as one of the most productive marine ecosystems after mangroves and coral reefs (Blankenhorn, 2007). Seagrass beds provide human needs for a long time, for example, Posidonia litter which has been used as a storage area for beds since the $16^{\text {th }}$ century (Terrados and Bodrum, 2004). Lamun ecosystem contribute to the overall marine ecosystems, both in the ecological and economic fields, including the capacity in stabilizing sediments, improving water quality, and its function in the carbon and nutrient cycle, and also serves to provide habitat for various forms of life in waters. coastal area (Hemming et al., 2000 in Nadiarti et al., 2012). In terms of the stability of Lamun ecosystems play a role in the productivity of coral reefs and other fisheries (Unsworth and Cullen, 2010), because Lamun have the ability to filter nutrients and sedimentation before burdening coral reefs. According to Mcleod in Nordlund et al., (2018), the distribution of seagrass populations is currently estimated to range between $177.000-600.000 \mathrm{~km}$, but due to various factors, both due to human activity and an increase in global climate causing a decline in seagrass populations, the estimated rate of decline ranges from 7\% globally (Waycott et al., 2009). Globally, the loss of seagrass beds between 1879 and 2006 was $27 \mathrm{~km}^{2}$ (Waycott et al., 2009). Efforts to conserve and coastal ecosystems in general have been carried out by the government, one of them is by issuing laws and regulations in Indonesia, law 31 of 2004 concerning fisheries and law 27 of 2007 concerning management of coastal areas and small islands, which states that seagrass ecosystems are part of fisheries management (Nadiarti et al., 2012; Mossa et al., 2018).

\section{Coral Reef Ecosystem}

Coral reef ecosystem, is a typical ecosystem located in the tropics, which is formed from calcium carbonate deposits (CaCO3) produced by reef-forming organisms (hermatipic corals) from the film Cnidaria of the order Scleractina which lives in symbiosis with zooxantellae and a few additions from calcareous algae and other organisms which secretes carbonates (Benget, 2002 in Lubis, 2013). Many coral reef ecosystems are used as tourist sites, around 30\% of the world's coral reefs are valued in the tourism sector, with a tot al value estimated at nearly US \$ 36 billion, or more than $9 \%$ of the value of coastal tourism in the world's coral reef countries (Spalding et al., 2017). Indonesia is an archipelagic country, which is one of the largest coral reef ecosystems. Coral reefs in Indonesia ha ve an area of $50,875 \mathrm{~km}^{2}$ which constitutes $18 \%$ of the world's total coral reefs (Burke et al., 2002). The rich ecosystems of the world's coral reefs are being threatened by both natural phenomena and human activities. Climate change is considered the most serious risk for coral reefs worldwide, agricultural pollution threatens around 25\% of the total area of global coral reefs (Burke, 2011 in Kroon et al. (2014). Several studies in the Solomon Islands have shown that human population density and market access increases fishing pressure, which in turn is a major driver of threats to farmers' stock and diversity (Brewer et al., 2012).

\section{Ecotourism and Regional Development}

The development of community based ecotourism areas, helps the government in increasing the level of welfare of the community in general, and the population around the ecotourism area in particular, this is in accordance with the opinion of Situmorang and Mirzanti (2012), ecotourism will significantly affect the local labor market and regional domestic products. Sustainable development of ecotourism areas requires effort and commitment from all parties, especially the government's attention in accommodating important dimensions in sustainable tourism development, according to Hasan (2015) there are 6 (six) important dimensions of green tourism namely:

a. Direct experience with the natural and cultural environment, environmentally friendly, socially, and psychologically acceptable;

b. Define the environment according to natural rules, not tourists;

c. Planning and participating in greentours;

d. Increasing the attention and ethics of tourists towards the environment;

e. Economic contribution to the tourism industry;

f. Directing part of the revenue for the natural resource area.

Fulfilling 6 (six) important dimensions of green tourism will help the government in meeting the needs of tourists, provide opportunities to increase economic growth, protect physical location, and improve the quality of life of the population while increasing opportunities going forward through the coexistence of tourism development and environmental quality (Eagles et al., 2002; Carvache et al., 2018; Carvache et al., 2019). The development of the Reusam Island ecotourism area also has the support of the Lhok Timon Village apparatus, this is in line with existing regulations, one of which is Law No. 6 of 2014 concerning Villages, according to Badaruddin et al., (2017) explains that through Law Number 6 of the year 2014 in addition to re-recognition of traditional villages, also gave greater autonomy for villages to be able to manage and develop villages in achieving national development goals, as well as achieving prosperous and equitable communities.

\section{Community Based Ecotourism Management}

Successful management of ecotourism and protected areas requires sustainable use of visitors, which requires the effective management of natural areas for the pleasure of visitors and the protection of resources for ever (WCED, 1987 in Farrell and Marion, 2001). In carrying out effective and sustainable ecotourism activities, it is necessary to understand some general characteristics of ecotourism, which have been identified by UNEP (2004) and the World Tourism Organization as:

a. Involving appreciation not only of nature, but also of indigenous cultures prevailing in natural areas, as part of the visitor experience;

b. Contains education and interpretation as part of travel offers;

c. generally, but not exclusively, organized for small groups by small, specialized and locally owned businesses;

d. Minimizing negative impacts on the natural and socio-cultural environment;

e. Support the protection of natural areas by producing economic benefits for managers of natural areas;

f. Providing alternative income and employment for local people;

g. Increase local and visitor awareness of conservation (WWF, 2001).

According to Das and Chatterjee (2015) the aim of ecotourism development is to protect certain areas through the provision of income, environmental protection, education and the involvement of local residents. The International Ecotourism Community defines ecotourism as responsible travel to natural areas that preserve the environment and sustain the welfare of the local community (WWF, 2001). Success in achieving these three things requires maximum effort, moreover to achieve all three goals at once, many obstacles such as political, economic and other interversions. According to Honey (2002) in Zambrano et al., (2009) to achieve each ecotourism goal must be supported by a set of clear standards and applied consistently, as occurs in areas with national or regional ecotourism certification programs, Protection Forests and so forth. In this case ecotourism becomes a reliable tool to improve the local economy, especially in disadvantaged areas. In remote and natural areas, ecotourism is responsible for generating income for environmental protection (Santarem et al., 2015). 


\section{Community Empowerment Around the Ecotourism Area}

The development of an ecotourism area, can not be separated from the involvement of local residents and communities around the ecotourism destination area, this is in accordance with the theory of complex ecosystems in ecotourism, which emphasizes the balance between socio-cultural, economic and environmental, of the three elements above there are interrelated interactions and complement each other. Based on the research results of Auesriwong et al., (2015) concluded that the Development of Community-Based Ecotourism which is Integrative to Sangkhom District succeeded in bringing together different stakeholders, and increasing stakeholder participation in the tourism planning process. Based on the results of Auesriwong's research, evidence of the development of community-based tourism has become an important tool for sustainable management (Sebele, 2010).

\section{Ecotourism as a Community-Based Conservation Facility}

The presence of ecotourism areas can be both positive and negative. It can positively affect people's living standards, increase income, create new jobs, improve local infrastructure, increase the availability of entertainment facilities, promote local identity, etc. However, tourism also has the potential to cause negative impacts by making the cost of living and micro crime increase, exacerbating population density and conflict disruption, and changing ecosystems (Chiappa et al., 2016). Community feelings play an important role in encouraging community support for the development and conservation of tourism areas (Abang et al., 2016). According to Farrell and Marion (2001), increasing community environmental education and community participation will greatly assist the conservation process in the area around ecotourism, making local communities appreciate the use of natural resources that are not only consumptive (Farrell and Marion, 2001). A similar sentiment was also conveyed by Tsung (2013) who understands the support of host citizens for the development of sustainable tourism is an important factor in the success of community-based tourism management and marketing.

\section{Sharia Tourism}

Growth in the Muslim population continues to increase throughout the world, making the Sharia tourism market increasingly in demand, so it is not surprising, many Sharia tourist destinations are found, although not in a predominantly Muslim country (Perbawasari et al., 2019a). In terms of implementation, there is a difference between Sharia tourism in majority countries and Muslim minorities (Sadalia et al., 2018). The application of Sharia tourism in non-Muslim majority countries is more oriented to Halal tourism.

\section{Development of World Sharia Tourism}

Growth and development of Islam is growing faster than other world religions, in 2010 the global Muslim population surpassed one billion and a half and is expected to increase to 2.2 Billion by 2030 (Pew Forum, 2011 in Carboni and Janati (2016). Muslim population in the world, also has a positive influence on the demand for Halal tourism markets that are part of Sharia-based tourism. According to Battour et al., (2016) the tourism industry recognizes the increasing interest of Halal tourists both from the point of view of practitioners and researchers. The rise in interest in Halal tourism is partly due to the growth of Muslim populations around the world. Muslim consumers are one of the fastest growing market segments and their needs cannot be ignored by destination providers and tourism operators (Battour and Ismail, 2014). In accordance with the World Islamic Economic Report, the global Muslim travel market was valued at \$ 140 Billion in 2013 , which is equivalent to $11.5 \%$ of global spending. The same report predicts that the segment is estimated to be worth $\$ 238$ Billion in 2019 and represents 13\% of global spending (Battour et al., 2016). At present there is a struggle for the Muslim tourist market which has led to countries such as Malaysia focusing more on attracting Muslims by developing their tourism industry to suit the needs of Muslim visitors (Al-Hamarneh and Steiner, 2004). Sharia tourism preparation is not only done by Malaysia, various developing countries, making tourism as one of the fastest growing sectors and effective tools for foreign investment and financial reserves, international tourism activities have become the main source of foreign exchange income for several OIC Member Countries such as Benin, Chad, Gambia, Maldives, Mali, Senegal, Sierra Leone and Uganda (Farahani and Eid, 2016). Carboni et al., (2014) added that Islamic tourism is not restricted to religious purposes and is not exclusive in Muslim countries. Islamic tourism attracts many non-Muslim tourists who are interested in what is called 'Islamic Culture'. Islamic culture in this case is Sharia and its practice by Muslims should not be considered static. Instead, Islam responds to cultural changes and changes in activities such as tourism. For example, in the case of Malaysia, there was a development of tourism that was different from the Western understanding in meeting the needs of Muslim visitors (Jafari and Scott, 2014).

\section{RESEARCH METHODS}

This research is a survey research, the data used in this study consists of primary data and secondary data. Primary data were obtained directly from the field, whereas for data on ecotourism potential, natural resource capacity and the application of Islamic Sharia were obtained through questionnaires. From the results of preliminary observations with the Lhok Timon Village Head (Geuchik) of Setia Bakti Subdistrict, it is estimated that the number of tourist visits on Sundays +500 people, assuming the data collection is carried out for 3 (three) months/12 weeks. So (500 people x 12 weeks) a total population of 6.000 was obtained. Determination of the number of samples is done by the Harry King Nomogram with an error rate of $10 \%$, we get a sample of tourists as much as $11 \%$ of the tourist population on Sundays or as many as 55 people every Sunday, then get (55 people x 12 weeks) the total sample is 660 people the sample.

\section{RESULT AND DISCUSSION}

\section{Characteristics of Respondents}

Several questions related to the respondent's personal data and the purpose of visiting Reusam Island in Table 1.

The most cost spent visiting Reusam Island is around IDR 1.000 .000 as many as $57.88 \%$ of visitors, and $22.88 \%$ of visitors spent as much as IDR. 2.000.000. 11.97\% of visitors spent IDR 3.000.000. And the rest that cost more than 3 million were 7.27\% visitors. Based on the results of the distribution of expenditure in point 6 above, if the management of the Reusam Island area is carried out in a professional manner and is able to attract the interest of tourists, it will directly be able to increase Aceh Jaya's local revenue in general and local communities around Reusam Island in particular. The distribution of economic turnover in Aceh Jaya Regency is no less than 4 billion every week with the assumption that the carrying capacity of Reusam Island is 4.153 people/day decent asebility on Reusam Island.

\section{Response to Carrying Capacity, SDA Capacity, Ecotourism Potential and Application of Islamic Sharia in Aceh.}

\section{Carrying capacity}

The distribution of the questionnaire about carrying capacity aims to determine the response of visitors to the satisfaction and readiness of the island of Reusam to become an ecotourism area show in Table 2. Changes in weather do not make visitors worried about changes in sea wave height. This can be seen from the response of visitors as much as $17.42 \%$ and $14.85 \%$ strongly disagree and disagree, while $18.33 \%$ 
choose neutral in this case, besides that as many as $29.70 \%$ and $19.70 \%$ choose to agree and strongly agree with the above statement. In an effort to anticipate the high waves and graceful, the manager of the Reusam Island tourist area took the stand by not carrying out crossings to the island until the weather supported heading to Reusam Island, this policy was taken in order to avoid things that are not desirable.

Table 1. Characteristics of Respondents

\begin{tabular}{|c|c|c|c|c|c|}
\hline No. & & Result & Total & & \\
\hline 1. Age & 11-20 Years & 21-30 Years & $31-40$ Years & $>41$ Years & \\
\hline Percentage (\%) & 22.88 & 45.00 & 21.36 & 10.76 & 100 \\
\hline 2. Sex & Male & Female & & & \\
\hline Percentage (\%) & 61.82 & 38.18 & & & 100 \\
\hline 3. Profession & Civil Servants/Military/Police & Farmers / fishermen / laborers & Student & Private \& others & \\
\hline Percentage (\%) & 9.55 & 38.03 & 30.00 & 22.42 & 100 \\
\hline 4. What was the last formal education you got & Elementary school equivalent & Middle school equivalent & High school equivalent & Collage & \\
\hline Percentage (\%) & 11.52 & 12.42 & 48.64 & 27.42 & 100 \\
\hline 5. Activities performed & Tourism & Research & Fishing & Others & \\
\hline Percentage (\%) & 55.91 & 3.48 & 29.70 & 10.91 & 100 \\
\hline $\begin{array}{l}\text { 6. How much did you spend to visit } \\
\text { Reusam Island }\end{array}$ & IDR 1.000 .000 & IDR 2.000 .000 & IDR 3.000 .000 & Others & \\
\hline Percentage (\%) & 57.88 & 22.88 & 11.97 & 7.27 & 100 \\
\hline 7. Do you visit Reusam Island when you stay? & Yes & Not & & & \\
\hline Percentage (\%) & 27.73 & 72.27 & & & 100 \\
\hline 8. When staying, where do you stay & The guesthouse & Family place & hotel & Others & \\
\hline Percentage $(\%)$ & 15.30 & 39.34 & 31.14 & 14.20 & 100 \\
\hline $\begin{array}{l}\text { 9. How was the tour experience that you } \\
\text { felt in visiting this tour? }\end{array}$ & Positive & Negative & & & \\
\hline Percentage (\%) & 88.94 & 11.06 & & & 100 \\
\hline $\begin{array}{l}\text { 10. How many times have you visited the } \\
\text { Object of Reusam Island? }\end{array}$ & One Time & Twice & Others & & \\
\hline Percentage (\%) & 66.21 & 24.70 & 9.09 & & 100 \\
\hline 11. Who are you visiting Reusam Island? & Alone & Family & Friend & Others & \\
\hline Percentage (\%) & 3.48 & 46.97 & 45.91 & 3.64 & 100 \\
\hline $\begin{array}{l}\text { 12. How do you know about this Reusam } \\
\text { Island attraction? }\end{array}$ & Print media & Electronic Media & Oral Information & Travel agencies \& more & \\
\hline Percentage (\%) & 2.27 & 53.48 & 40.30 & 3.94 & 100 \\
\hline 13. The nature of your visit to Reusam Island? & The main purpose & Next destination & Transit & Others & \\
\hline Percentage $(\%)$ & 62.88 & 25.91 & 3.94 & 7.27 & 100 \\
\hline Percentage $(\%)$ & 100 & 0 & & & 100 \\
\hline
\end{tabular}

Table 2. Community Response Towards carrying capacity

\begin{tabular}{|c|c|c|c|c|c|c|c|}
\hline No & Question & Strongly Disagree & Disagree & Neutral & Agree & Strongly Agree & Total \\
\hline \multicolumn{8}{|c|}{ Carrying capacity } \\
\hline 1 & $\begin{array}{l}\text { The number of visitors visiting Reusam Island does not interfere with my } \\
\text { comfort while on Reusam Island }\end{array}$ & 7 & 18 & 93 & 338 & 204 & 660 \\
\hline \multicolumn{2}{|r|}{ Percentage $(\%)$} & 1.06 & 2.73 & 14.09 & 51.21 & 30.91 & 100 \\
\hline 2 & $\begin{array}{l}\text { The most comfortable time I was on Reusam Island for a tour }+-240 \\
\text { minutes ( } 4 \text { hours). If the answer does not agree, state another time ... Clock }\end{array}$ & 21 & 12 & 214 & 224 & 189 & 660 \\
\hline \multicolumn{2}{|r|}{ Percentage $(\%)$} & 3.18 & 1.82 & 32.42 & 33.94 & 28.64 & 100 \\
\hline 3 & $\begin{array}{l}\text { The state of the land (the risk of erosion) does not make me worry about } \\
\text { being on Reusam Island. }\end{array}$ & 6 & 24 & 134 & 179 & 317 & 660 \\
\hline \multicolumn{2}{|r|}{ Percentage $(\%)$} & 0.91 & 3.64 & 20.30 & 27.12 & 48.03 & 100 \\
\hline 4 & Changes in weather make me worried about changes in sea wave height & 115 & 98 & 121 & 196 & 130 & 660 \\
\hline \multicolumn{2}{|r|}{ Percentage $(\%)$} & 17.42 & 14.85 & 18.33 & 29.70 & 19.70 & 100 \\
\hline 5 & $\begin{array}{l}\text { The number of management officers available is sufficient to manage the } \\
\text { activities of Reusam Island tourism }\end{array}$ & 299 & 241 & 52 & 38 & 27 & 660 \\
\hline \multicolumn{2}{|r|}{ Percentage $(\%)$} & 45.30 & 36.52 & 7.88 & 5.76 & 4.09 & 100 \\
\hline 6 & The professionalism of the security team is sufficient & 309 & 268 & 45 & 22 & 16 & 660 \\
\hline \multicolumn{2}{|r|}{ Percentage $(\%)$} & 46.82 & 40.61 & 6.82 & 3.33 & 2.42 & 100 \\
\hline
\end{tabular}

\section{Natural Resource Capacity}

Table 3 show about community response to natural resources capacities below. Public response about the capacity of natural resources on the island of Reusam to be used as an ecotourism area, almost all items received a positive response from visitors, except about the coral reefs on the island of Reusam which are used for diving and snorkeling destinations. The beauty of diving and snorkeling destinations. $49.85 \%$ and $28.64 \%$ of visitors answered strongly disagree and disagree, $11.82 \%$ neutral. While $5.61 \%$ of visitors chose to agree, and $3.64 \%$ of visitors strongly agreed, in addition there were $0.45 \%$ did not give a choice. Based on the community's response, an active role of the Aceh Jaya Regional Government is needed across other sectors, in the continued development of coral reef cultivation that has been carried out before, but due to the lack of attention and care after the initial steps.

\section{Ecotourism Potential}

A total of 7 (seven) questionnaire questions about community responses to the potential of ecotourism aim to find out community knowledge, as well as Government support for the management of ecotourism areas, for more details, see Table 4 below. Community response to the ecotourism potential of Reusam Island received a positive response, except in terms of Government support for the management of ecotourism areas on Reusam Island, most of the endorsers still doubted the commitment of the local government, this can be seen from 660 visitors, as much as $8.33 \%$ and $12.12 \%$ answered strongly disagree and disagree, $19.24 \%$ neutral and as much as $33.18 \%$ chose to agree, the remaining $27.12 \%$ strongly agreed. 
Table 3. Community Response to Natural Resources Capacities

\begin{tabular}{|c|c|c|c|c|c|c|c|}
\hline No & Question & Strongly Disagree & Disagree & Neutral & Agree & Strongly Agree & Total \\
\hline \multicolumn{8}{|c|}{ Natural Resources Capacities } \\
\hline 1 & The interior level of the seawater is very good for coastal ecotourism. & 30 & 32 & 347 & 124 & 118 & 660 \\
\hline \multicolumn{2}{|r|}{ Percentage $(\%)$} & 4.55 & 4.85 & 52.58 & 18.79 & 17.88 & 100 \\
\hline \multicolumn{2}{|r|}{ Percentage $(\%)$} & 2.42 & 3.48 & 12.27 & 40.61 & 41.21 & 100 \\
\hline 3 & Current speed does not make me worry to swim and dive in the sea & 24 & 33 & 230 & 217 & 156 & 660 \\
\hline \multicolumn{2}{|r|}{ Percentage $(\%)$} & 3.64 & 5.00 & 34.85 & 32.88 & 23.64 & 100 \\
\hline 4 & Sea water brightness is very appropriate for the ecotourism region & 54 & 38 & 82 & 249 & 237 & 660 \\
\hline \multicolumn{2}{|r|}{ Percentage $(\%)$} & 8.18 & 5.76 & 12.42 & 37.73 & 35.91 & 100 \\
\hline 5 & Sandy Beach Type Adds Beauty to Reusam Island & 20 & 31 & 112 & 248 & 249 & 660 \\
\hline \multicolumn{2}{|r|}{ Percentage $(\%)$} & 3.03 & 4.70 & 16.97 & 37.58 & 37.73 & 100 \\
\hline 6 & The size of the land cover does not make me worry to visit Reusam Island & 59 & 44 & 88 & 205 & 257 & 660 \\
\hline \multicolumn{2}{|r|}{ Percentage $(\%)$} & 8.94 & 6.67 & 13.33 & 31.06 & 38.94 & 100 \\
\hline 7 & Fresh water available on the island is very adequate & 261 & 237 & 118 & 28 & 16 & 660 \\
\hline \multicolumn{2}{|r|}{ Percentage $(\%)$} & 39.55 & 35.91 & 17.88 & 4.24 & 2.42 & 100 \\
\hline 8 & $\begin{array}{l}\text { There is a Coral Reef on the island of Reusam. adding to the beauty of } \\
\text { diving and snorkeling }\end{array}$ & 329 & 189 & 78 & 37 & 24 & 660 \\
\hline \multicolumn{2}{|r|}{ Percentage $(\%)$} & 49.85 & 28.64 & 11.82 & 5.61 & 3.64 & 100 \\
\hline 9 & There are various types of fish for fishing & 46 & 47 & 234 & 188 & 126 & 660 \\
\hline \multicolumn{2}{|c|}{ Percentage $(\%)$} & 6.97 & 7.12 & 35.45 & 28.48 & 19.09 & 100 \\
\hline
\end{tabular}

Table 4. Community Response to Ecotourism Potential

\begin{tabular}{|c|c|c|c|c|c|c|c|}
\hline No & Question & Strongly Disagree & Disagree & Neutral & Agree & Strongly Agree & Total \\
\hline & Ecotourism Potential & & & & & & \\
\hline 1 & $\begin{array}{l}\text { Making Reusam Island. An ecotourism area. will protect the flora and } \\
\text { fauna of Reusam Island }\end{array}$ & 7 & 14 & 98 & 332 & 209 & 660 \\
\hline \multicolumn{2}{|r|}{ Percentage $(\%)$} & 1.06 & 2.12 & 14.85 & 50.30 & 31.67 & 100 \\
\hline 2 & Ecotourism is a means of environmental management & 8 & 9 & 59 & 291 & 285 & 660 \\
\hline \multicolumn{2}{|r|}{ Percentage $(\%)$} & 1.21 & 1.36 & 8.94 & 44.09 & 43.18 & 100 \\
\hline 3 & $\begin{array}{l}\text { The application of the concept of ecotourism on Reusam Island will } \\
\text { reduce the impact of environmental degradation. }\end{array}$ & 7 & 10 & 33 & 299 & 306 & 660 \\
\hline \multicolumn{2}{|r|}{ Percentage $(\%)$} & 1.06 & 1.52 & 5.00 & 45.30 & 46.36 & 100 \\
\hline 4 & $\begin{array}{l}\text { Aceh Jaya Regency Government's support for the development of the } \\
\text { Ecotourism area has been very maximal }\end{array}$ & 55 & 80 & 127 & 219 & 179 & 660 \\
\hline \multicolumn{2}{|r|}{ Percentage $(\%)$} & 8.33 & 12.12 & 19.24 & 33.18 & 27.12 & 100 \\
\hline 5 & $\begin{array}{l}\text { The concept of ecotourism plays an important role in the promotion of } \\
\text { local cultural assets and customs }\end{array}$ & 11 & 21 & 25 & 344 & 259 & 660 \\
\hline \multicolumn{2}{|r|}{ Percentage $(\%)$} & 1.67 & 3.18 & 3.79 & 52.12 & 39.24 & 100 \\
\hline 6 & Ecotourism can increase income for the people around Reusam Island & 9 & 14 & 27 & 343 & 259 & 659 \\
\hline 7 & $\begin{array}{l}\text { The existence of an ecotourism area on Reusam Island will provide } \\
\text { environmental education for the people. }\end{array}$ & 4 & 6 & 10 & 284 & 356 & 660 \\
\hline \multicolumn{2}{|r|}{ Percentage $(\%)$} & 0.61 & 0.91 & 1.52 & 43.03 & 53.94 & 100 \\
\hline
\end{tabular}

\section{Application of Islamic Sharia}

Knowing the community's response to the management system of Reusam Island so far. And the community's response to the Shariabased ecotourism itself. In addition to knowing visitors' knowledge of the application of Islamic Sharia. It can be seen in Table 5. Respondents about the bathing facilities available on the island of Reusam. Whether it is in accordance with the rules of the application of Islamic Sharia in Aceh. As many as 31.21\% of respondents answered strongly disagree. 29.39\% answered disagreed and $12.73 \%$ chose neutral answers. $13.94 \%$ answered agreed and $11.06 \%$ strongly agreed.

Table 5. People respond to the application of Islamic law in the area of ecotourism Reusam

\begin{tabular}{|c|c|c|c|c|c|c|c|}
\hline No & Questions & Strongly Disagree & Disagree & Neutral & Agree & Strongly Agree & Total \\
\hline & Implementation of Islamic Sharia & & & & & & \\
\hline 1 & $\begin{array}{l}\text { Bathing facilities available on the island of Reusam. Are in accordance } \\
\text { with the rules of the application of Islamic Sharia in Aceh. }\end{array}$ & 206 & 194 & 84 & 92 & 73 & 660 \\
\hline \multicolumn{2}{|r|}{ Percentage $(\%)$} & 31.21 & 29.39 & 12.73 & 13.94 & 11.06 & 100 \\
\hline 2 & $\begin{array}{l}\text { The operational means of transportation to Reusam Island. Are in } \\
\text { accordance with Islamic Sharia rules. }\end{array}$ & 171 & 211 & 77 & 102 & 96 & 659 \\
\hline \multicolumn{2}{|r|}{ Percentage $(\%)$} & 25.91 & 31.97 & 11.67 & 15.45 & 14.55 & 99.85 \\
\hline 3 & $\begin{array}{l}\text { The application of Islamic Sharia in Aceh supports the continuity of } \\
\text { tourism/ecotourism activities in Aceh Jaya. }\end{array}$ & 14 & 20 & 45 & 276 & 305 & 660 \\
\hline \multicolumn{2}{|r|}{ Percentage $(\%)$} & 2.12 & 3.03 & 6.82 & 41.82 & 46.21 & 100 \\
\hline 4 & $\begin{array}{l}\text { The development of the Reusam Island tourism area is in accordance } \\
\text { with the concept of applying Islamic Sharia in Aceh }\end{array}$ & 159 & 194 & 78 & 111 & 105 & 660 \\
\hline \multicolumn{2}{|r|}{ Percentage $(\%)$} & 24.09 & 29.39 & 11.82 & 16.82 & 15.91 & 100 \\
\hline 5 & $\begin{array}{l}\text { Sharia-based ecotourism management on Reusam Island can prevent } \\
\text { illegal activities (Alcohol and Drugs) }\end{array}$ & 3 & 7 & 5 & 307 & 338 & 660 \\
\hline \multicolumn{2}{|r|}{ Percentage $(\%)$} & 0.45 & 1.06 & 0.76 & 46.52 & 51.21 & 100 \\
\hline 6 & $\begin{array}{l}\text { Accommodations around Reusam Island. Already follow the rules of } \\
\text { Islamic Shari'ah. }\end{array}$ & 8 & 12 & 167 & 258 & 213 & 660 \\
\hline \multicolumn{2}{|r|}{ Percentage $(\%)$} & 1.21 & 1.82 & 25.30 & 39.09 & 32.27 & 100 \\
\hline
\end{tabular}




\section{Discussion}

The correlation formed between the components in the application of Islamic Sharia and the components in the socio-cultural element. Is a mutually reinforcing relationship between the two components/sub-systems. Thus giving a direct impact on the management and sustainability of Sharia-based ecotourism on Reusam Island. The application of Islamic Sharia in Aceh will indirectly shape the character and pattern of life of the people of Aceh generally and Aceh Jaya in particular. As is well known. That in the Islamic Religion requires its adherents to maintain harmony and foster tolerance with all groups. The positive impact of the implementation of Sharia does not only form an attitude of tolerance towards fellow human beings. But also requires humans to preserve the environment. In order to support the application of the Shari'a. The determination of carrying capacity of visitors to the Reusam Island ecotourism area. Not only concerns the environment. But also the suitability of Qanun number 6 of 2014. For examples paying attention to the capacity of prayer facilities. Human resources and sea transportation facilities that are separate between the male and female. The growth of Sharia tourism. Which is included in the special interest tour is not only due to the increase in the world's Muslim population. Muda et al. (2018), state that Indonesia which is one of the largest Muslim populations, also the encouragement of the teachings of Islam itself. Which requires Muslims to travel in order to increase their faith by observing the results Allah's creation. In order to support the development of tourism with special interest. With the concept of Sharia-based ecotourism on Reusam Island. All its activities must be adjusted to the application of Islamic Sharia in Aceh Jaya.

\section{CONCLUSSION}

The potential carrying capacity of Reusam Island. In generally is in accordance with the needs of the HSalal ecotourism area in Aceh Jaya. Including weather changes. Efforts to anticipate the high waves and graceful. The manager of the Reusam Island tourist area takes a stand by not carrying out crossings to the island until the weather supports heading to Reusam Island. This policy was taken in order to avoid things that are not wanted. Besides the weather conditions. Another problem is the lack of management officers both in terms of quantity and quality. Public response about the capacity of natural resources on the island of Reusam to be used as an ecotourism area. Almost all items received positive responses from visitors. Except about the coral reefs on the island of Reusam which are used for diving and snorkeling destinations. Public response to the ecotourism potential of Reusam Island received a positive response. Except in terms of Government support for the management of the ecotourism area on Reusam Island. Most of the endorsers still doubted the commitment of the local government. As for Sharia tourism. All respondents agreed on the Reusam Island to be a Sharia ecotourism area.

\section{REFERENCES}

Abang, A.B., Khedif, A., Bohari, Z., \& Ali, J.K. (2016). Ecotourism Product Attributes and Tourist Attractions. Procedia-Social and Behavioral Sciences. 224. 360-367. https://doi.org/110.1016/j.sbspro.2016.05.388.

Ablain, M., Cazenave, G., Valladeao, G., \& Guinehut, S. (2009). A New Assessment of The Error Budget of Global Mean Sea Level Rate Estimated By Satellite Altimetry Over 1993-2008. Ocean Sci. 5(2), 193 -201. https://hal.archives-ouvertes.fr/hal-00990932/.

Adrianto, L. (2004). Sustainable Development and Management of Small Islands, PKSPLIPB. https://doi.org/10.13140/RG.2.2.12985.67684

Al-Hamarneh, A., \& Steiner, C. (2004). Islamic tourism: Rethinking the strategies of tourism development in the Arab world after September 11, 2001. Comparative Studies of South Asia. Africa and the Middle East, 24(1), 173-182. https://muse.jhu.edu/article/181197/pdf.

Arkema, K.K., Guannel, G., Verutes, G., Wood, S.A., Guerry, A., Ruckelshaus, M., \& Silver, J. M. (2013). Coastal habitats shield people and property from sea-level rise and storms. Nature climate change, 3(10), 913-918. https://doi.org/10.1038/nclimate1944.

Auesriwong, A., Nilnoppakun, A., \& Parawech, W. (2015). Integrative participatory community-based ecotourism at Sangkhom District, Nong Khai province, Thailand. Procedia Economics and Finance, 23(1), 778-782. https://doi.org/10.1016/S2212-5671(15)00529-8.

Badaruddin, B., \& Ermansyah, E. (2017). Proposing a Model for Law Number 6 of 2014: Evidence from North Sumatra. International Journal of Economic Perspectives, 11(4), 188-198.

Badaruddin, Revida, E., \& Muda, I. (2017). Village governance with implementation of law number 6 of 2014 on the village and village administration International Journal of Economic Research, 14(17), 389-402. http://repository.usu.ac.id/handle/123456789/69423.

Baksir, B. (2010). Management of Small Islands for the Utilization of Sustainable Ecotourism in the Districts of South Morotai and South Morotai. Dissertation. Bogor Agricultural University Postgraduate School. https://repository.ipb.ac.id/handle/123456789/26712.

Battour, M., Nazari, M, \& Ismail. (2016). Halal Tourism: Concepts, Practises, Challenges and Future. Tourism Management Perspectives. 19 150-154. https://doi.org/10.1016/j.tmp.2015.12.008

Battour, M., \& Ismail, M. N. (2014). The Role of Destination Attributes in Islamic Tourism. SHS Web of Conferences, 12, 01077. www.shs-conferences.org > ref > 2014/09 > shsconf 4 ictr2014 01077.

Blankenhorn, S.U. (2007). Seaweed Farming and Artisanal Fisheries. Indonesian Seagrass Bed-Complementary or Competitive Usages? PhD Thesis. Universität Bremen, Bremen, Germany. https://epic.awi.de/id/eprint/17186/1/Bla2007d.pdf.

Brewer, T.D., Cinner, J. E., Fisher, R., Green, A., \& Wilson, S.K. (2012). Market access, population density, and socioeconomic development explain diversity and functional group biomass of coral reef fish assemblages. Global Environmental Change, 22(2), 399-406. https://doi.org/10.1016/j.gloenvcha.2012.01.006.

Buchsbaum, B.D. (2004). Ecotourism and Sustainable Development in Costa Rica. Virginia Polytechnic and State University, USA. https://vtechworks.lib. vt.edu/handle/10919/9912.

Burke, L., Kathleen, R., Mark, S., \& Allison, P. (2002). Reefat Risk Revisitedin the Coralriangle. Washington DC: World Resources Institute. https://stgwedocs.unep.org/bitstream/handle/20.500.11822/19781/Reefs_at_Risk_Revisited.pdf?sequence=1.

Butar, R., \& Soemarno, S. (2013). Environmental effects of ecotourism in Indonesia. Journal of Indonesian Tourism and Development Studies, $1(3), 97-107$.

Carboni, M., \& Janati, M.I. (2016). Halal Tourism De Facto: A Case from Fez. Tourism Management Perspectives, 19(1)155-159. https://doi.org/10.1016/j.tmp.2015.12.007

Carboni, M., Perelli, C., \& Sistu, G. (2014). Is Islamic Tourism Viable Option For Tunisian Tourism? Taurism Management Perspective, 11-19, https://doi.org/10.1016/j.tmp.2014.02.002

Carvache-Franco, M., Carvache-Franco, O., \& Peñafiel, M. (2018). The Tourist Demand from the Perspective of the Motivation. Assessment and Satisfaction in a Sun and Beach Destination. GeoJournal of Tourism and Geosites, 22(2), 561-572. https://doi.org/10.30892/gtg.22224-311.

Carvache-Franco, M., \& Segarra-Oña, M. (2019). Motivations Analysis in Ecotourism through an Empirical Application: Segmentation. Characteristics and Motivations of the Consumer. GeoJournal of Tourism and Geosites, 24(1), 60-73. https://doi.org/10.30892/gtg.24106-343.

Chiappa, G.D., Atzeni, M., \& Ghasemi, V. (2016). Community-Based Collaborative Tourism Planning In Islands: A Cluster Analysis in the Context of Costa Smeralda. Journal of Destination Marketing and Management, 20, 2212-571X. https://doi.org/10.1016/j.jdmm.2016.10.005

Das, M., \& Chatterjee, B. (2015). Ecotourism: a Panacea or a Predicament? Tourism Management Perspect, 14(1), 3-16. https://doi.org/10.1016/j.tmp.2015.01.002

Eagles, P.F.J., McCool, S.F., \& Haynes, C.F. (2002). Sustainable Tourism in Protected Area: Guidelines or Planning and Management Gland. Switzerland: International Union for the Conservation of Nature. https://www.e-unwto.org/doi/abs/10.18111/9789284405435.

Eshun, G., Tichaawa, T.M. (2019). Reconsidering Participation for Local Community Well-Being in Ecotourism in Ghana. GeoJournal of Tourism and Geosites, 27(4). 1184-1200. https://doi.org/10.30892/gtg.27406-425.

Fandeli, C., \& Mukhlison. (2000). Ecotourism Exploitation. UGM. Yogyakarta. https://opac.perpusnas.go.id/DetailOpac.aspx?id=504533.

Farahani, H.Z., \& Eid, R. (2016). Muslim world: A Study of Taorism \& Pilgrimage among OIC Member States. Tourism Management Perspectives, 19, 144149. https://doi.org/10.1016/j.tmp.2015.12.009.

Farrell, T.A., \& Marion, J. (2001). Identifying and Assessing Ecotourism Visitor Impacts at Eight Protected Areas. Environmental Conservation, 28(3), 215225. https://doi.org/10.1017/S0376892901000224 
Gong, B., Liu, G., Liao, R., Song, J., \& Zhang, H. (2017). Endophytic Funguspur pure ocilliumsp. Brazilian journal of microbiology, 48(1), 530-536. http://dx.doi.org/10.1016/j.bjm.2016.10.027.

Hasan, A. (2015). Tourism Marketing. CAPS (Center for Publishing service). Jakarta. https://scholar.google.co.id/citations?user=QTUg3FUAAAAJ\&hl=id.

Jafari, J., Scott, N. (2014). Muslim World and Its Tourisms. Annals of Tourism Research, 44, 1-19. https://doi.org/10.1016/j.annals.2013.08.011.

Jones, J., Bartjan, J.W., Pennink, \& Wahyuni, S. (2011). Research Methodology. Guide for Masters of Ph.D in Management. Jakarta: Salemba Empat. https://www.belbuk.com/metodologi-penelitian-panduan-untuk-master-dan-phd-di-bidang-manajemen-p-20820.html.

Kemenpar. (2015). Final Report of Sharia Tourism Development Study. Republic of Indonesia. Jakarta. http://www.kemenparekraf.go.id/asset_admin/assets/uploads/media

Kilipiris, F., \& Zardava, S. (2012). Developing Sustainable Tourism in a ChangingEnvironment: Issues for the Tourism. Procedia - Social and Behavioral Sciences, 44-52. https://doi.org/10.1016/j.sbspro.2012.05.003.

Kolosinska, M., Petrashchak, O., \& Katana, A. (2018). Tourism Sector in Transition Economy on Example of Ukraine. GeoJournal of Tourism and Geosites. 21(1). 239-252. https://doi.org/10.30892/gtg.21119-284.

Kroon, F.J., Schaffelke, B., \& Bartley, R. (2014). Informing Policy to Protect Coastal Coral Reefs: Insight from a Global Review of Reducing Agricultural Pollution to Coastal Ecosystems. Marine Pollution Bulletin, 85, 33-41. https://doi.org/10.1016/j.marpolbul.2014.06.003.

Kurniawan, A., Hasan, G.J., Ooi, S.K., Kit, L.W., Loh, L.L., \& Bayen, S. (2014). Understanding hydrodynamic flow characteristics in a model mangrove ecosystem in Singapore. APCBEE procedia, 10, 286-291. https://doi.org/10.1016/j.apcbee.2014.10.054.

Lubis, H. (2013). Management of the Sibolga City Poncan Gandang Island for Ecotourism, Dissertation, Medan: USU, Postgraduate School. http://repository.usu.ac.id/bitstream/123456789/18631/4/Chapter\%20I.pdf.

Marzouki, M., Froger, G., \& Ballet, J. (2012). Ecotourism versus Mass Tourism. A Comparison of Environmental Impacts Based on Ecological Footprint Analysis. Journal Sustainability, 4, 123-140. https://doi.org/10.3390/su4010123.

Muda, I., Panjaitan, R., Ginting, S., \& Maksum, A. (2018). Model application of Murabahah financing acknowledgement statement of Sharia accounting standard. No 59, Year 2002. IOP Conf. Series: Earth and Environmental Science, 126(1), 012071. doi:10.1088/1755-1315/126/1/012071.

Muda, I., \& Wahyuni, E. (2019). An Analysis on the Effect of Environmental Performance and the Implementation of Environmental Management System on the Issuer Financial Performance. Calitatea, 20(168), 113-117.

Mossa, A., Camúñez-Ruiz, J. A., \& Morandi, F. (2018). Current state of the first UNESCO global Geopark: a case study of the geological and Mining Park of Sardinia, Italy. GeoJournal of Tourism and Geosites 22(2), 403-418. https://doi.org/10.30892/gtg.22211-298.

Nadiarti, Riani, E., Djuwita, I., \& Asmus, U. (2012). Challenging For Seagrass Management in Indonesia. Journal of Coastal Develpopment, 15(3), 234-242. https://pdfs.semanticscholar.org/86a3/32ab1e1bd7d60bf4bfb88fe135e9ceb01f8c.pdf.

Nanlohy, H., Bambang, A.N., \& Hutabarat, MS. (2015). Coastal Communities Knowledge Level on Climate Change as a Consideration in Mangrove Ecosystems Management in West Seram. Procedia Environmental Sciences, 23, 157-163. https://doi.org/10.1016/j.proenv.2015.01.024.

Niell, R.E., Kousky, C., Thompson, A., \& Walls, M. (2017). Threatened Protection: Sea Level Rise and Coastal Protected Lands of The Eastern United States. Ocean \& Coastal Management, 137, 118 - 130. https://doi.org/10.1016/j.ocecoaman.2016.12.014.

Nordlund, L.M., Jackson, E.L., Nakaoka, M., Samper-Villarreal, J., Beca-Carretero, P., \& Creed, J. C. (2018). Seagrass ecosystem services-What's next? Marine pollution bulletin, 134, 145-151.

Ozyurt, G., \& Ergin, A. (2009). Application of Sea Level Rises Vulnerability Assessment Model to Selected Coastal Areas. Journal of coastal research, 12(1), 79-89. https://www.jstor.org/stable/25737575.

Perbawasari, S., Dida, S., Nugraha, A.R., \& Sjuchro, D.W. (2019a). Indung Management Communication Model to Establishment of Tourism Identity Based On Sundanese Cultural Values. GeoJournal of Tourism and Geosites, 27(4), 1201-1211. https://doi.org/10.30892/gtg.27407-426.

Perbawasari, S., Sjuchro. D.W., \& Nugrahar, A.R. (2019b). Halal Tourism Communication Formation Model in West Java. Indonesia. GeoJournal of Tourism and Geosites. 25(2). 309-320. https://doi.org/10.30892/gtg.25203-361.

Pohan, N., Dalimunthe, R. F., Purwoko, A., \& Muda, I. (2018). The Effects of Human Resource Development and Institutional Arrangements on Performance, Service Quality and Area Development in Indonesia. Quality-Access to Success, 19(163), 94-102.

Sadalia, I., Kautsar, M. H., Irawati, N., \& Muda, I. (2018). Analysis of the efficiency performance of Sharia and conventional banks using stochastic frontier analysis. Banks \& bank systems, 13(2), 27-38, doi: 10.21511/bbs.13(2).2018.03.

Salm, R.V., Clark, J.R., \& Siirila, E. (2000). Marine and coastal protected area: A Guide for Planners and Managers. Third Edition. International Union for Conservation of Natureand Natural Resources. Gland. Switzerland. https://www.iucn.org/content/marine-and-coastal-protected-areas-a-guide-planners-and-managers-0.

Santarem, F., Silva, R., \& Santos, P. (2015). Assessing ecotourism potential of hiking trails: A framew ork to incorporate ecological and cultural features and seasonality. Tourism Management Perspectives, 16, 190-206. https://doi.org/10.1016/j.tmp.2015.07.019.

Schlüter, T., \& Schumann, A. (2018). Geosites as a Potential for fhe Development of Tourism-Overview of Relevant Sites in Eswatini. GeoJournal of Tourism and Geosites, 22(2), 535-547. https://doi.org/10.30892/gtg.22222-309.

Sebele, L.S. (2010). Community-Based Tourism Ventures. Benefits and Challenges: Khama Rhino Sanctuary Trust. Central District Botswana. Tourism Management, 31, 136-146. https://doi.org/10.1016/j.tourman.2009.01.005.

Sembiring, R., Herlinda, E., Ningsih, S., \& Muda, I. (2019). The Role of Dalihan Na Tolu in Enhancing the Tourism Appeal of Parbaba White Sand Beach in Samosir Regency as Indonesia's National Geopark. GeoJournal of Tourism and Geosites. 26(3), 701-713. https://doi.org/10.30892/gtg.26302-390.

Short, F., Carruthers, T., Dennison, W., \& Waycott, M. (2007). Global seagrass distribution and diversity: a bioregional model. Journal of Experimental Marine Biology and Ecology, 350(1-2), 3-20. https://doi.org/10.1016/j.jembe.2007.06.012.

Situmorang, D.B., \& Mirzanti, I.R. (2012). Social Entrepreneur shipto Develop Ecotourism. Procedia Economics and Finance, 4, 398-405. https://doi.org/10.1016/S2212-5671(12)00354-1.

Spalding, M., Ruffo, S., Lacambra, C., \& Meliane, I.H. (2014). The Role of Ecosystems. Ocean coast Manag. 90. 50e57. https://doi.org/10. 1016/j.ocecoaman.2013.09.007.

Terrados, J., \& Bodrum, J. (2004). Why are Seagrasses Important? - Goods and Services. Seagrass. 8-10. http://www.seagrasses.org.

Tondang, B. (2007). Nias Island Special Interest Tourism Center. Scientific Journal of Tourism, 3(1), 155-167. https://ojs.unud.ac.id/index.php/destinasipar.

Tsung, H.L. (2013). Influence Analysis of Community Resident Support for Sustainable Tourism Development. Tourism Management, 34, 37-46. https://doi.org/10.1016/j.tourman.2012.03.007.

Unsworth, R. K., \& Cullen, L. C. (2010). Recognising the necessity for Indo-Pacific seagrass conservation. Conservation Letters, 3(2), 63-73.

Umilia, E. (2016). Formulation of Mangrove Ecosystem Management Model. Procedia-Social and Behavioral Sciences, 227, 704-711. https://doi.org/10.1016/j.sbspro.2016.06.136.

Vujko, A., Tretiakova, T.N., Dimitrić, D., \& Vuković, D. (2018). Demographic Monitoring and Forecasting Tourists'arrivals as a Means of Overcoming Seasonality. GeoJournal of Tourism and Geosites, 22(2), 524-534. https://doi.org/10.30892/gtg.22221-308.

Waycott, M., Duarte, C.M., \& Carruthers, T.J.B. (2009). Accelerating Loss of Sea grasses Across the Globe Threatens Coastal Ecosystems. Proc. Natl. Acad., 2377-2381.

Widagdyo, K.G. (2015). Analysis of the Indonesian Halal Tourism Market. The Journal of Tauhidinomics, 1(1), 73-80. http://journal.uinjkt.ac.id/index.php/ tauhidinomics/article/view/3325.

Zambrano, A.A., Broadbent, E.N., \& Duham, W.H. (2010). Social and Environmental Effects of Ecotourism in the Osa Peninsula of Costa Rica. Journal of Ecotourism, 9(1), 62-83. https://doi.org/10.1080/14724040902953076.

*** Republic of Indonesia (2014). Law Number 6 of 2014 Article 71 describes village finance. Jakarta.

*** Central Statistical Board (2013). Aceh Jaya Regency 2013. Aceh Jaya Regency Area. https://acehjayakab.bps.go.id/.

*** UNEP (2004). Seagrass in the South China Sea. Nairobi. Kenya. https://www.pnas.org/content/106/30/12377.short.

*** UNEP (DEC) MED WG (2005). Draft Protocol on Integrated Coastal Zone Management in the Mediterranean. Meeting of the MAP Focal Points. Athens. Greece. 2124 September 2005. Retrieved from https://wedocs.unep.org/bitstream/handle/20.500.11822/5515/05wg270_5_eng.pdf?sequence=1\&isAllowed=y.

*** World Wide Fund for Nature (2001). Guideline for community-based ecotourism development. WWF International. https://wwf.panda.org/?12002/ Guidelines-for-Community-based-Ecotourism-Development. 